$10-2014$

\title{
Business Ethics and Ideals
}

Gregory Wolcott

Loyola University Chicago, gwolcot@luc.edu

Follow this and additional works at: https://ecommons.luc.edu/business_facpubs

Part of the Business Commons

\section{Recommended Citation}

Wolcott, Gregory. Business Ethics and Ideals. Business Ethics Journal Review, 2, 6: 36-41, 2014. Retrieved from Loyola eCommons, School of Business: Faculty Publications and Other Works, http://dx.doi.org/ 10.12747/bejr2014.02.06

This Article is brought to you for free and open access by the Faculty Publications and Other Works by Department at Loyola eCommons. It has been accepted for inclusion in School of Business: Faculty Publications and Other Works by an authorized administrator of Loyola eCommons. For more information, please contact ecommons@luc.edu.

\section{(c) (1) (\$)}

This work is licensed under a Creative Commons Attribution-Noncommercial-No Derivative Works 3.0 License. (c) Gregory Wolcott, 2014. 


\title{
Business Ethics and Ideals
}

\author{
Gregory Wolcott ${ }^{1}$
}

A commentary on John Hasnas (2013), “Teaching Business Ethics: The Principles Approach,” J Bus Ethics Ed 10: 275-304, http://doi.org/10.5840/jbee201310 $\underline{14}$

\begin{abstract}
John Hasnas (2013) argues for a "Principles Approach" to supplant normative theory and casuistry in business ethics pedagogy. This Commentary argues some normative theory ought still to have some place in business ethics education and that the problems Hasnas sees in business ethics pedagogy only tell half the story.
\end{abstract}

IN A PROVOCATIVE and compelling article, John Hasnas (2013) ${ }^{2}$ addresses failures in business ethics pedagogy. Such failures are the result of professors falling prey to either the Scylla or the Charybdis of business ethics pedagogy. The Scylla in business ethics pedagogy is the tendency to prioritize highly abstract philosophical theories that are then applied to "particular ethical problems" in business [276]. When take to extremes, this approach employs concepts and language far removed from the business world, and thus it remains "virtually unintelligible to the audience [i.e., the students] it is intended to reach” [276]. The Charybdis is the tendency to eschew any abstract theory in favor of casuistry, which Hasnas describes as the use of case-based analyses where students identify the impacts of business

${ }^{1}$ Loyola University Chicago. Email: gwolcot@luc.edu

${ }^{2}$ Bracketed page references in the text are to Hasnas (2013). 
decisions for various ends. This approach rarely questions the "legitimacy" of those ends [278], nor does it use any normative principles that would guide the determination of the cases" "morally relevant" factors [276]. Hasnas labels this "unstructured intuitionism": because it is unmoored to anything in the realm of normativity, it reduces "ethical" conclusions to mere opinions about the best courses of actions [276-277]. Either way, students are not provided any useful guidance for how to behave ethically in their business careers.

Hasnas proposes that we navigate these waters through the "Principles Approach." He promises a series of non-exhaustive but "fundamentally important" principles that bridge the gap between normativity and actual business practice and that can serve as a guide for students throughout their college careers [296]. Because it uses principles that flow directly from the nature of market activity itself and from the principal-agent relationship [283], this approach holds, in Hasnas's view, a unique advantage over the aforementioned tactics. Namely, it meets a number of "challenges" that arise in business ethics pedagogy: (1) the difficulty of defining and defending business ethics pedagogy; (2) the problem of highly abstract theories (including mediating theories like normative stakeholder theory [280]); (3) the tendency of students to conflate the fact of cultural relativism with ethical relativism; and, finally, (4) the task of integrating ethics education across a curriculum [278-283].

For the purposes of this Commentary, I will not focus on the principles Hasnas chooses or on his belief that this approach answers the challenges as well as he claims. It appears plausible that his approach could solve some of the problems that plague business ethics pedagogy [291-295], but some of these matters will be settled empirically. However, I have a series of concerns with his argument, especially as it regards the status of normative theory in business ethics pedagogy. I think we ought to hold out hope that there is some space for normative theory, if handled judiciously, within a business ethics course. Where it would fit, however, is a problem raised but not adequately addressed by Hasnas himself. He claims that the Principles Approach can be supplemented by "additional considerations," presumably including theory [291, 292n12]. The problem is how those same additions can be incorporated safely without undoing the very work that employing the Principles Approach is supposed to achieve —and we are given no clues by Hasnas as to how that might work (on 
this point, I would welcome further suggestions from Hasnas). Therefore, in addition to offering a few minor critical comments about Hasnas's argument, this Commentary intends to say something about the value of incorporating, carefully, some normative theory into business ethics pedagogy. Indeed, Hasnas's argument about the state of business ethics pedagogy is almost irresistible, but only if we tell part of the story.

\section{1}

To begin, I carve up our risks a bit differently. I agree that the Scylla is overuse of poorly handled abstract normative theory, though I say more on this, soon. And though I agree that atheoretical casuistry is a problem, I identify a different Charybdis: turning business ethics pedagogy into an education of how to comply with the law. Though current laws embody many ethical beliefs, it would be frightening to say that the law should be the arbiter or summation of what is right and wrong, as opposed (primarily) to a codification of some accepted practices. Too much emphasis on compliance with the law, or even casually highlighting that "the law says $\mathrm{X}$ with regard to issue $\mathrm{Y}$," has the unintended effects of (1) seducing students into conflating the ethics with law and (2) suggesting to students that their ethical responsibilities begin and end with what the law dictates. Business law is, undoubtedly, an important element in a business school curriculum. I doubt, too, that any business ethicist intentionally reduces ethics to extant law, but the heavy reliance on what the law says in business ethics textbooks does suggest an underlying message: all that matters is avoiding fines and staying out of jail. ${ }^{3}$

\section{2}

Hasnas also claims that it's not necessary to emphasize normative theory in business ethics classrooms if students already take courses in general ethics [292n12]. This position, however, leads to some head scratchers. First, if students are taught normative theory anyhow, and presumably are capable of understanding it, this undercuts a major

3 Clayton Christensen (2012), who advises business persons to look at how they will "measure their lives," lists "How can I be sure that I live a life of integrity—and stay out of jail?" as one of the three main questions that business persons should ask themselves (2012: 6). In the history of heroes of martyrdom and civil disobedience persons whose integrity has landed them in jail (or worse) - one is propelled to ask this question: what does one have to do with the other conceptually? 
motivation for the Principles Approach-namely, that normative theory lessons are too incomprehensible to be relevant [292]. Second, some instructors of business ethics, aware that normative theory has already been taught in other classes, simply review the central elements of normative theory with the students for the purposes of applying them in a way that is more applicable to the subject matter of business. When that's the case, and if it can be done successfully, it's even more reason to be wary of Hasnas's claim about the value of the Principles Approach as a compelling alternative to normative theory.

Third, given that Hasnas is understandably concerned about ethics discussions devolving into mere expressions of intuitions, why wouldn't lessons on normative theories - which attempt to give fundamental justifications for normative claims - be the appropriate cure? Students, for example, already believe it's usually wrong, unless qualifiers are supplied, to use physical coercion to get their way (to use one of Hasnas's principles [286]). Why not provide them with the intellectual resources to see why such behavior is wrong? Hasnas claims that the justifications he provides are the ones that flow from universal market activity itself, and that this avoids having to try to convince students of the rightness of any particular normative theory (which, he rightly claims, could take a whole course [281]). But there are other options on the table that do not eschew normative theory entirely. An instructor could choose, for instance, to adopt one particular normative framework for the entirety of the course (such as virtue ethics), and in so doing provide students with those deeper intellectual resources to articulate why, for example, physical coercion is usually wrong both within and outside market activity. Such a tactic may help address the relativism problem in a more sustained way, especially because relying solely or primarily on the Principles Approach tells students nothing about the ethics of the principles outside their business careers. ${ }^{4}$ Additionally, this could aid the integration of ethics in students' entire curricula, not just their business training.

\section{3}

The choice of virtue ethics as an example of the normative theory an instructor might adopt in business ethics courses was not random on

${ }^{4}$ Many think that the problem of relativism is a fundamental problem for virtue ethics. However, universalist and essentialist versions of virtue ethics avoid this pitfall. 
my part, and it gets to the bigger problem I see with the Principles Approach. Despite my quite minor quibbles, I think Hasnas has done an exceptional job both in identifying problems with business ethics pedagogy and in offering a worthwhile alternative to current approaches to it, especially when either tendency gets taken to extremes. However, the real failure of business ethics pedagogy is the fact that too many students enter and leave business schools believing that ethics and real success in business are ultimately incompatible.

I do not think this problem will disappear by using basic normative theory, casuistry, or principles alone. In fact, all may have some role to play in helping students identify and address the nuances of transacting in a morally upright way in the commercial arena. However, there's more to be said about what business ethics courses should aspire to, and that demands a sea change in the way that business schools understand and emphasize the moral goodness of a business vocation and the marketplace in which businesses operate.

Part of that will come from the tools provided by virtue ethics as a type of normative theory - insofar as virtue ethics emphasizes, as its fundamental concerns, what it means to be a flourishing individual and the importance of cultivating shared goods internal to various practices (which is a possible area of overlap between the Principles Approach and virtue ethics as a normative theory).

Pursuing this tack means expanding the expectations for college education and pushing students to think more broadly about the value of their education. An ethics course, even business ethics, gives students perhaps their only sustained opportunity throughout college to reflect upon and think critically about who they are and what they may become-and how that relates to their chosen business careers. In the tradition of virtue ethics, asking students hard questions about what they believe and why, as well as how they understand their pursuits and themselves in a world full of goods that may be enjoyed, probably does not fit an administrative committee's demands for learning outcomes, but it does cohere with the ideals of liberal education. For fear of getting pedagogy wrong, my real concern is that business schools have forgotten what is right.

Received 20 September 2014 / Posted 20 October 2014 


\section{REFERENCES}

Christensen, C. 2012. How Will You Measure Your Life? New York: HarperCollins.

Hasnas, J. 2013. “Teaching Business Ethics: The Principles Approach,” J Bus Ethics Ed 10: 275-304, http://doi.org/10.5840/jbee20131014 